\title{
CONIDIAL FUNGI FROM Salix herbacea LEAF LITTER AND THEIR GROWTH TEMPERATURE PREFERENCES
}

\author{
(Hongos conidiales de hojas de litera de Salix herbacea y sus temperaturas \\ preferenciales de crecimiento)
}

Oliveira Longa Claudia Maria, Palma Luisa, Tosi Solveig

Sezione di Micologia, Dipartimento di Ecologia del Territorio e degli Ambienti Terrestri, Università di Pavia, via S. Epifanio 14, 27100, Pavia, stosi@et.unipv.it

Key words: Conidial fungi, leaf litter, Salix herbacea, temperature.

Palabras clave:Hongos conidiales, litera, Salix herbacea, temperatura.

\begin{abstract}
A preliminary qualitative analysis was carried out on fungal composition of leaf litter of Salix herbacea growing on Gran Sasso, Monti della Laga (TE), the highest mountain of the Apennines. Direct isolation in humid chamber and culture of soil on plates were used as methods. The most isolated genera were Acremonium, Cladosporium, Lecanicillium, Mucor, Penicillium and Pestalotia. Lag period and radial growth of the colonies were recorded at different temperatures from -1 to $45^{\circ} \mathrm{C}$. and the optimal temperature for growth and sporulation was detected for each isolate. Most of the isolated strains were psychrotolerant mesophyle and capable to grow within a $1^{\circ} \mathrm{C}$ to $+30^{\circ} \mathrm{C}$ range, except for a thermotolerant strain of Penicillium that could grow at $45^{\circ} \mathrm{C}$. They exhibited a wide range of thermal tolerance together with their ability to grow in habitats which are commonly submitted to great changes in temperature similar to those occurring in alpine climate. Data presented in this paper can be useful to understand the ecological requirements of the fungal components of high mountain ecosystems that are often subject to monitoring in the investigation of the effects of global climatic changes.
\end{abstract}

\section{INTRODUCTION}

Alpine climate areas are considered extreme environments, where temperatures can be extremely low for long periods and organisms highly adapted with short summer period for growth (Müller \& Magnuson, 1987). Alpine summer daylight is considerably short

\section{RESUMEN}

Se realizó un análisis cualitativo de la composición fúngica de hojas de la litera de Salix herbacea que crece en Gran Sasso, Monti della Laga(TE), en la alta montaña de los Apeninos. El método utilizado fue el aislamiento directo en cámara humeda y el cultivo del suelo en placas. Los géneros más aislados fueron: Acremonium, Cladosporium, Lecanicillium, Mucor, Penicillium y Pestalotia. Se registró la fase lag y el crecimiento radial de las colonias a diferentes temperaturas, desde-1 hasta $45^{\circ} \mathrm{C}$ y se detectó la temperatura óptima de crecimiento y esporulación para cada aislado. La mayoría de las cepas aisladas fueron mesófilas psicrotolerantes y capaces de crecer en un rango de $1{ }^{\circ} \mathrm{C} \mathrm{a}+30^{\circ} \mathrm{C}$, excepto una cepa de termotolerante de Penicillium que pudo crecer hasta $45^{\circ} \mathrm{C}$. Ellas presentaron un amplio rango de tolerancia térmica, destacandose su especialidad para crecer en los hábitats caracterizados por altos cambios de temperatura semejante a los del clima alpino. Los datos presentados en este trabajo pueden ser usados para entender los requerimientos ecológicos de los componentes fúngicos de los ecosistemas de alta montaña sujetos a monitoreo en las investigaciones de los efectos del cambio climático global.

although light intensity is high and therefore sunlight may appreciably warm the ground and rock. Therefore alpine environment can be subject to rapid and extreme changes of temperature, especially at the microhabitat level. The fungal component of alpine environments (Mosca, 1957, 1960; Dal Vesco,1974; Piontelli \& Caretta,1974; Bisset \& Parkinson, 1979 a, b, c; Piontelli et al., 1986), like that of 
polar regions (Del Frate \& Caretta, 1990; Bergero et al., 1999; Onofri et al., 2000, 2004; Tosi et al., 2005), seems to be different in its species composition from that of other biogeographical regions. A lot of taxa that are widespread and dominant in temperate regions are absent in the tundra and alpine areas. Structure and composition of the fungal community changes with altitude, e.g. richness of species decreases (Schinner \& Gstraunthaler, 1981). Strains of a single species from different climatic areas have different thermal requirements. In polar areas fungal strains are ecophysiologically highly adapted at low temperatures and most of them are psychrofilic and psychrotolerant; the only thermotolerants are those from the heated area of Antarctic volcanoes. (Zucconi et al., 1996; Bergero et al., 1999). The knowledge of fungi from cold extreme areas can be important when these areas are often monitored for the effects of global warming (Cattle \& Crossler, 1995) being highly sensitive to climatic changes and offering a unique opportunity to study the effect of climatic changes on a global scale. To this purpose, experiments of climatic manipulated condition were conducted in Antarctica to study the effects of artificial warming and UV radiation on soil fungi. Quantitative and qualitative changes were recorded after 3 years of conditioning (Tosi et al., 2005). Climate evolution may force the nival species of plants and their associated fungi to find shelter in small areas of extreme climate conditions, where their expansive capacity would be close to nil (Grabherr et al., 1995, 2001; Chlebicki, 2002).

Salix herbacea (dwarf willow) is one of the endangered species of the Italian mountains as a consequence of climatic warming. It is an arctic-alpine relict species with a disjoined distribution (Pignatti, 1982; Chlebicki, 2002) and the Gran Sasso is the southernmost limit of its distribution area in Italy. Italian alpine environments have been poorly investigated by mycologists (Buratti et al., 2001; Tosi et al., 2002a, b); no data are available on filamentous fungi associated with the Italian population of Salix herbacea.

In this paper qualitative results on fungal species isolated from the leaf litter of Salix herbacea growing on the summit of Gran Sasso (Apennine, Central Italy), are presented. Thermal requirements for growth and sporulation of the isolates are also given.

\section{MATERIALS AND METHODS}

Litter samples of Salix herbacea $\mathrm{L}$. were collected in July 2001, in a nival valley at ca. 2400 m.s.l. on the west slope of Corno Grande (Gran Sasso National Park, Monti della Laga, Te, Italy), the highest mountain in the Apennines. A total of 10 samples consisting of ca. $10 \mathrm{~g}$ of litter were aseptically collected from a $100 \mathrm{~m} \times 100 \mathrm{~m}$ area. The sampling sites were at least $10 \mathrm{~m}$ from each other. 92
All the samples were separately stored in sterile plastic bags and transported to the laboratory at $2^{\circ} \mathrm{C}$, then analyzed. Three isolation media were used: sterile moist filter paper, Potato Dextrose Agar (PDA) and Malt Extract Agar (MEA, Sigma Aldrich, Steinheim, Germany). Streptomycin sulphate and potassium penicillin $\mathrm{G}$ were added to achieve final concentrations of $30 \mathrm{ppm}$ and $20 \mathrm{ppm}$, respectively. Sprinkle plate was used as isolation technique. The plates were prepared by uniformly distributing $0,5 \mathrm{~g}$ litter of each sample directly on the surface of the medium. For each medium, each sample was distributed onto six plates and incubated at 8 or $20^{\circ} \mathrm{C}$ (three plates each). A total of 180 plates were prepared. Isolations were made after one week of incubation for 1 month. Taxonomic identifications were performed in the laboratories of the authors. Cultures were stored on Sabouraud's «conservation» medium in glass screwed-caps vials at $2{ }^{\circ} \mathrm{C}$.

The influence of temperature on the growth rate, sporulation and lag period (period preceding growth after inoculation) was tested for each isolate. Four plates (50 $\mathrm{mm}$ in diam.) containing $10 \mathrm{ml}$ of PDA, were inoculated (punctiform inocula) with the same strain and incubated in refrigerated or heated air incubators, at $-1,8,15,20$, $25,30,37,45^{\circ} \mathrm{C}$ (32 plates for each strain). Cultures were protected from desiccation by the use of plastic bags. At different temperatures the growth rate of each fungus was daily recorded by measuring the diameter of the colony and mean value and standard deviation of four growth rate measurements were calculated. The radial growth of the colonies was recorded for a 30 day total.

Lag periods and occurrence of sporulation were also estimated at the testing temperatures in each isolate.

\section{RESULTS AND DISCUSSION}

More than 100 strains of filamentous fungi were

Table 1. Isolated fungal taxa from Salix herbacea leaf litter

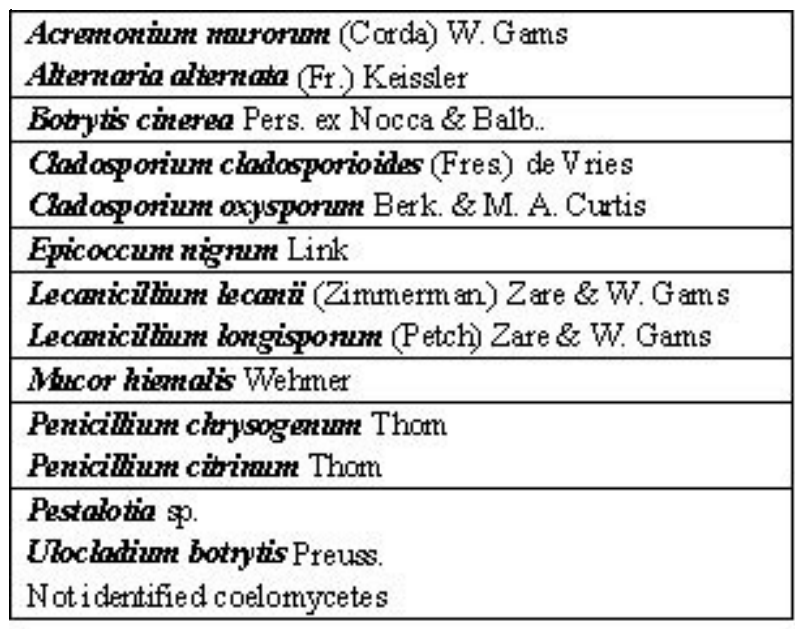



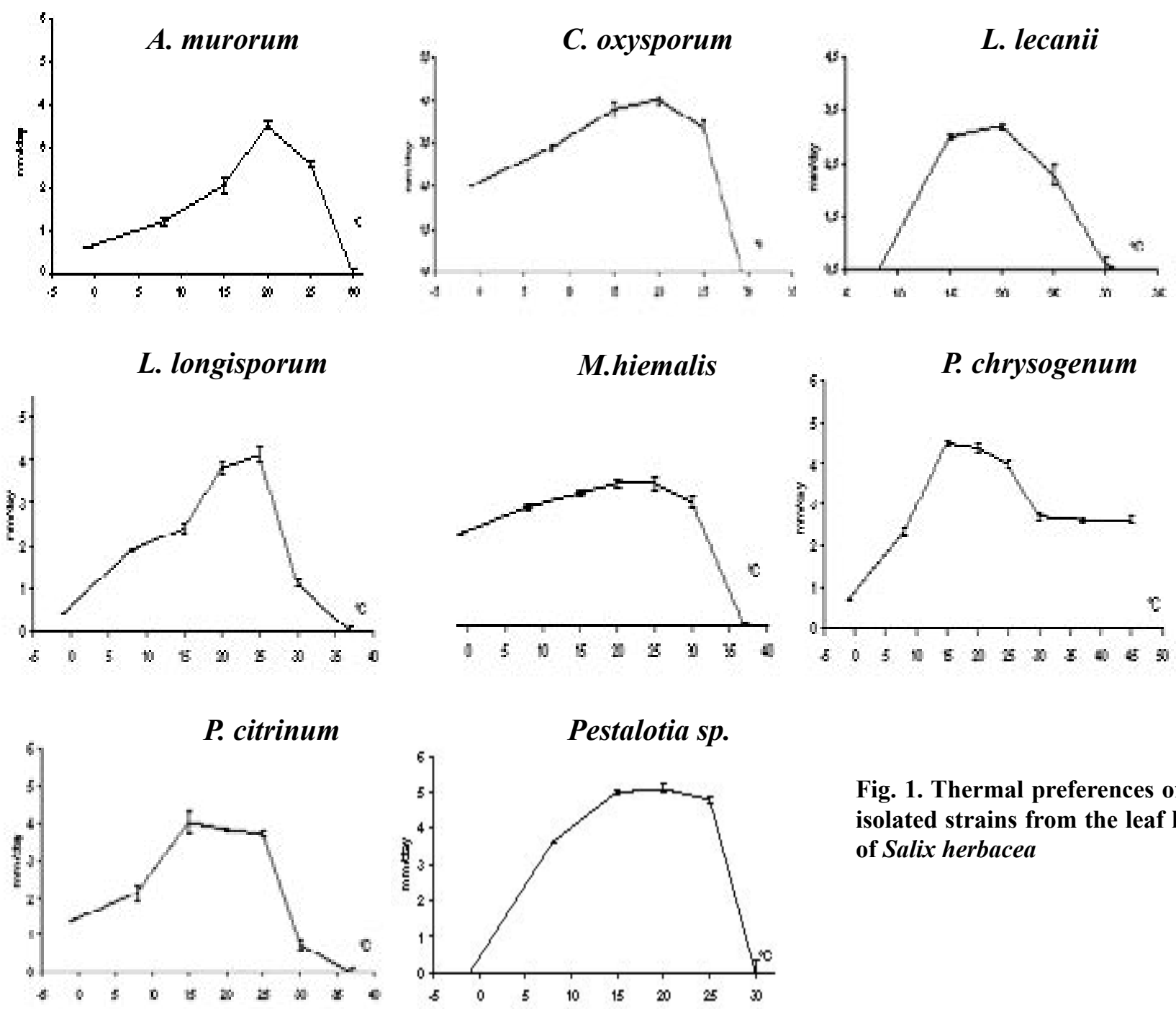

Fig. 1. Thermal preferences of the isolated strains from the leaf litter of Salix herbacea

\begin{tabular}{|c|c|c|c|c|c|c|c|c|}
\hline & \multicolumn{8}{|c|}{ Tenperature ${ }^{\circ} \mathrm{C}$} \\
\hline Fungal taxa & -1 & 8 & 15 & 20 & 25 & 30 & 37 & 45 \\
\hline A. murorwm & 30 & 22 & 10-S & $40-S$ & 4 & & & \\
\hline Coxpsporzm & $16-S$ & $4 \mathrm{~S}$ & $4 \mathrm{~S}$ & $40-S$ & 4S & & & \\
\hline L.lecan ü & & 20 & $4-S$ & $40-S$ & $4 S$ & 4 & & \\
\hline L. bongisporum & 50 & 16 & 4 & 4 & $40-S$ & 10 & & \\
\hline M. hiomalis & 22 & 10 & 4S & $40-S$ & $40-S$ & 4 & & \\
\hline P.chrysogenum & 43 & 16 & $40-S$ & $4-S$ & $4-S$ & 4 & 4 & 4 \\
\hline P.citumum & 16 & 10 & $40-S$ & $4-S$ & 4-S & 4 & & \\
\hline Pestalotia sp. & & 15 & 40 & $4-0$ & 4 & & & \\
\hline
\end{tabular}

Table 2. Number of days preceding growth (lag period) in all temperatures tested; $O=$ optimum; $S=$ start of sporulation; the range of temperature for growth is in grey.

isolated from the litter of Salix herbacea, belonging to 10 genera and 12 species, listed in Tab. 1. Besides, many colonies of coelomycetes were directly observed growing in plates. No differences in fungal species composition were recorded among the 10 sampling sites. From a qualitative point of view fungal assemblage colonizing Salix herbacea litter seems to be quite poor. Most of the recorded species have a worldwide distribution, e.g. Acremonium murorum, Alternaria alternata, Botrytis cinerea, Epicoccum nigrum. Cladosporium oxysporum and $\boldsymbol{C}$. cladosporioides were the most frequently isolated species. Some of these isolated seem to be highly specialized; Lecanicillium lecanii showed a strong nematophagous activity in Petri dish and L. longisporum 
is often reported from insects (Zare \& Gams, 2001). Data on thermal preferences, occurrence of sporulation and lag periods of the isolates are shown in Tab.2. Radial growth rate of the colonies and range of testing temperature are plotted in Fig. 1. According with Kirk et al. (2001), most of the strains can be classified as psychrotolerant, being able to grow at $-1{ }^{\circ} \mathrm{C}$, with an optimum temperature for growth at $20-25^{\circ} \mathrm{C}$. The strain of Penicillium citrinum can be considered psychrophile having $15^{\circ} \mathrm{C}$ as an optimum temperature for growth, and able to grow at $-1^{\circ} \mathrm{C}$. On the contrary the strain of $\boldsymbol{P}$. chrysogenum is thermotolerant being able to grow at $45^{\circ} \mathrm{C}$, with optimum at $15-20^{\circ} \mathrm{C}$. All the tested fungi, a part from $P$. chrysogenum, failed to grow at $37^{\circ} \mathrm{C}$ or over. Cladosporium oxysporum, $\boldsymbol{A}$. murorum, and Pestalotia sp. failed at $30^{\circ} \mathrm{C}$. Lag periods of each tested strain are reported in Table 2 and they show the start of the fungal metabolic activity at different temperatures. For all the isolates the shortest lag periods are between 15 and $30^{\circ} \mathrm{C}$ and under these conditions sporulation occurs reflecting the mesophilic preference of the strains. Generally speaking, microfungi with high growth rates in narrow temperature ranges could be well adapted to thermally stable environments. Conversely, microfungi with wide temperature ranges would be well adapted to wide temperature variations in the environment.

Bergero, B.; Girlanda, M.; Varese, G.C.; Intini, D. \& Luppi, A.M. (1999). Psychrooligotrophic fungi from Arctic soils of Franz Joseph Land. Polar Biology 21:361-368

Bisset, J. \& Parkinson, D. (1979a). The distribution of fungi in some alpine soils. Can. J. Bot. 57:1609-1629

Bisset, J. \& Parkinson, D. (1979b). The fungal community structure in some alpine soils. Can. J. Bot. 57:1630-1641

Bisset, J. \& Parkinson, D. (1979c). Functional relationship between soil fungi and environment in alpine tundra. Can. J. Bot .57:1642-1659

Buratti C.; Solari N. \& Tosi S. (2001). Caratterizzazione tassonomica ed ecofisiologica di funghi associati a piante e suolo di un area dell'Appennino Settentrionale monitorata per il cambiamento climatico. Arch. Geobot. 7:75-81

Cattle, H. \& Crossley, J. (1995). Modelling Arctic climate change.

Philosophical Transactions of the Royal society of London A 352:201-
Assuming the curves width at half of the maximum growth rate to be an indicator of the adaptation of the species to environmental thermal instability, as proposed by Zucconi et al. (1996), it could be claimed that some species were more suitable than others. Acremonium murorum, Lecanicillium lecanii and $\boldsymbol{P}$. citrinum seem to be less adapted to the thermal instability. They could represent some of the unstable species of the alpine environment, highly influenced by climatic change. Studies about the alpine mycota and collection of data on its thermal tolerance could be very important in climatic change monitoring programmes that have high mountain environments as models and it must be considered in refining projections of global climatic change effects.

\section{Acknowledgements}

We whish to thank the University of Pavia (Italy) for financial support (F.A.R.), Prof. G. Pacioni of the University of L'Aquila (Italy) for kindly collecting material and Prof. G. Caretta of the University of Pavia for suggesting improvements to the manuscript.

\section{REFERENCES}

Chlebicki, A. (2002). Biogeograhic relationships between fungi and selected glacial relict plants. Monographiae Botanicae; Journal of the Polish Botanical Society 90:230

Dal Vesco, G. (1974). Funghi del suolo di un pianoro acquitrinoso in Valle di Cogne (Aosta). Allionia 20:81-92

Del Frate, G. \& Caretta, G. (1990). Fungi isolated from Antarctic material. Polar Biology 11:1-7

Grabherr, G.; Gottfried, M.; Gruber, A. \& Pauli, H. (1995). Patterns and current changes in alpin plant diversity. In Stuart Chapin III F. \& Korner C. (eds.); Arctic and Alpine biodiversity: 167-181. Ecological Studies 113, Springer

Grabherr, G.; Gottfried, M.; Gruber, A. \& Pauli, H. (2001). Aspect of global change in the Alps and in the high arctic region. Long term monitoring in alpin plant diversity. In Stuart Chapin III F. \& Korner C. (eds.); Arctic and Alpine biodiversity. Ecological Studies 113. Springer. pp.167-181

Horak, E. (1960). Die Pilzvegetation im Gletschervorfeld (2290-2350 m) des Rotmoosferners in den Ötztaler Alpen. Nova Hedwigia Z. Kryptogamenkd. 2:487-507

Kerry, E. (1990). Effects of temperature on growth rates of fungi from subantarctic Macquarire Island and Casey; Antarctica. Polar Biology 10:293-299 
Kirk, P. M.; Cannon, P. F.; David, J. C. \& Stalpers, J. A. (2001).

Piontelli, E.; Toro, M.A. \& Casanova, D.Z. (1986). Microcomunidades fungicas en zona altiplanica chilena. Estudio sobre substratos queratinicos. Rev. Arg. Micologia 9:26-32

Dictionary of the Fungi: 655 pp

Mosca, A. M. (1957). Ricerche sulla microflora del terreno di una valletta nivale nel Parco Nazionale del Gran Paradiso. Allionia; 3: 83-107

Schinner, F. \& Gstraunthaler, G. (1981). Adaptation of microbial Mosca, A. M. (1960). Sulla microflora del terreno di un pascolo alpino in val di Lanzo (Alpi Graie). Allionia; 6:17-34

Onofri, S.; Fenice, M.; Cicalini, A.R.; Tosi, S.; Magrino, A.; Pagano, S.; Selbmann, L.; Zucconi,L.; Vishniac, H.; Ocampo-Friedmann, R.; Friedmann, E.I. (2000). Ecology and biology of microfunghi from Antarctic rocks and soils. Italian Journal of Zoology 1:163-167

activities to the environmental conditions in alpine soils. Oecologia

Onofri, S.; Selbmann, L.; Zucconi, L.; Tosi, S.; de Hoog, G.S. (2004). The Mycota of Continental Antarctica. Terra Antarctica Reports 11:37-42

Pignatti, S. (1982). Flora d'Italia. Edagricole

Piontelli, E. \& Caretta, G. (1974). Considerazioni ecologiche su alcuni geomiceti isolati su substrati cheratinici; in località montagnose delle Ande del Cile. Rivista di Patologia vegetale 10: 261-314 